P ISSN 2356-1637 | E ISSN 2581-0103

\title{
PERTIMBANGAN PUTUSAN HAKIM PERKARA HARTA BERSAMA N0.0233/PDT.G/2018/PA.TBH DI PENGADILAN AGAMA TEMBILAHAN
}

\author{
Azmil Fauzi Fariska \\ Universitas Islam Negeri Sunan Kalijaga Yogyakarta \\ azmilfauzi7@gmail.com
}

\begin{abstract}
This research was motivated by the decision of the Tembilahan Religious Court judges who decided the joint property case in which the judge decided the Plaintiff (husband) got $1 / 4$ while the Defendant (wife) got $3 / 4$ of the shared property. However, Article 97 in the Compilation of Islamic Law states that: "Widows or widowers are each entitled to half of the joint property as long as it is not stipulated otherwise in the marriage agreement." This research is in the form of library research using case No.0233/Pdt.G/2018/PA.Tbh, as the primary reference, while the secondary material in this paper consists of laws and regulations related to the object of the research decision No. 0233/Pdt.G/2018/PA.Tbh as well as books, journals, scientific works related to the object of research. The author's data collection technique uses interview techniques and study documents or library materials. The results of the verdict research are in accordance with the judge in deciding the case based on Legal Certainty (legal certainty) and Legal Justice (legal justice), legal certainty is what has been outlined by the laws and regulations, Compilation of Islamic Law, like this case according to legal certainty then the distribution it is the wife gets $1 / 2$ and the husband also gets $1 / 2$ then if only this which is applied rigidly in the case will reduce the values of justice itself, thus the judge in determining the joint property case uses Legal Justice.
\end{abstract}

Keywords: Joint Assets, KHI, Legal Certainty, Legal Justice.

\begin{abstract}
Abstrak
Penelitian ini dilatarbelakangi oleh putusan majelis hakim Pengadilan Agama Tembilahan yang memutuskan perkara harta bersama yang mana hakim memutuskan Penggugat (suami) mendapatkan $1 / 4$ sedangkan Tergugat (istri) mendapatkan $3 / 4$ dari harta bersama. Akan tetapi, dalam Kompilasi Hukum Islam pasal 97 menyebutkan bahwa: "Janda atau duda cerai masing-masing berhak seperdua dari harta bersama sepanjang tidak ditentukan lain dalam perjanjian perkawinan." Penelitian ini berbentuk penelitian pustaka (library research) dengan menggunakan perkara No.0233/Pdt.G/2018/PA.Tbh, sebagai rujukan primernya,
\end{abstract}


sedangkan bahan sekundernya dalam tulisan ini terdiri dari peraturan perundangundangan yang terkait dengan objek penelitian putusan No.0233/Pdt.G/2018/PA.Tbh serta buku, jurnal, karya ilmiah yang ada kaitannya dengan objek penelitian. Teknik pengumpulan data penulis menggunakan teknik wawancara dan studi dokumen atau bahan pustaka. Hasil penelitian putusan sesuai dengan hakim dalam memutuskan perkara itu berdasarkan Legal Certainty (kepastian hukum) dan Legal Justice (keadilan hukum), kepastian hukum adalah apa yang sudah digariskan oleh peraturan perundang-undangan, Kompilasi Hukum islam, seperti perkara ini menurut legal certainty maka pembagian nya adalah isteri mendapat $1 / 2$ dan suami pun mendapat $1 / 2$ maka jika hanya ini yang diberlakukan secara kaku dalam perkara tersebut akan mereduksi nilai-nilai keadilan itu sendiri, dengan demikian hakim dalam menetapkan perkara harta bersama ini menggunakan Legal Justice (Keadilan Hukum).

Kata kunci: Harta Bersama, KHI, Legal Certainty, Legal Justice

\section{Pendahuluan}

Menurut Undang-undang Nomor 1 tahun 1974, perkawinan adalah ikatan lahir bathin antara seseorang pria dengan wanita sebagai suami isteri dengan tujuan membentuk keluarga (rumah tangga) yang bahagia dan kekal berdasarkan Ketuhanan yang Maha Esa. ${ }^{1}$ Demi membentuk keluarga yang bahagia dibutuhkan rasa saling memahami antara suami isteri sehingga dapat tercipta keharmonisan, ketenangan dan kasih sayang karena ketiga poin tersebut merupakan kunci dari tujuan perkawinan. Sebagaimana firman Allah Swt, Surat Ar-Rum ayat 21 yang berbunyi;

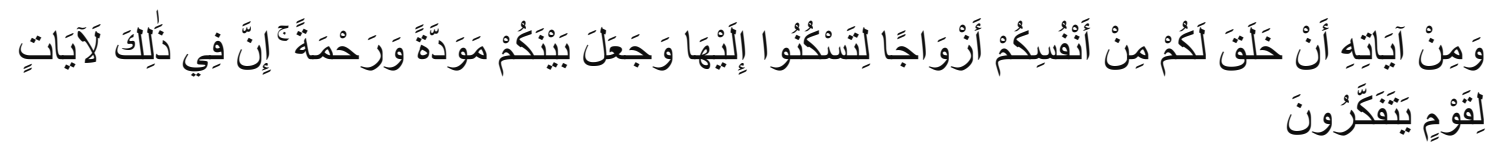

"Dan di antara tanda-tanda kekuasaan-Nya ialah Dia menciptakan untukmu isteri-isteri dari jenismu sendiri, supaya kamu cenderung dan merasa tenteram kepadanya, dan dijadikan-Nya diantaramu rasa kasih dan sayang. Sesungguhnya pada yang demikian itu benar-benar terdapat tandatanda bagi kaum yang berfikir."2

Pernikahan juga merupakan rahmat dan nikmat dari Allah.Melalui pernikahan tersebut manusia bisa merasakan ketenangan, kasih sayang, dan kedamaian. Namun tidak setiap pasangan yang terikat dalam perkawinan tersebut dapat menyelesaikan misinya dengan sempurna, dalam perkawinan akan terjadi pergejolakan dalam rumah tangga yang berawal dari faktor-faktor tertentu. Pergejolakan tersebut akan membawa pernikahan kepada perceraian suami isteri yang tidak menemui jalan penyelesaian. Suami isteri sendiri dalam ajaran Islam tidak boleh terlalu cepat mengambil keputusan bercerai walaupun perceraian

\footnotetext{
${ }^{1}$ Hasbullah Bakry, Kumpulan Lengkap Undang-undang dan Peraturan Perkawinan di Indonesia (Jakarta: Djambatan, 1985).3

${ }^{2}$ Kementerian Agama RI, Al-Qur'an dan Terjemahannya (Jakarta: CV Madinatu al-'Ulum,2012).406
} 
tersebut dibolehkan. ${ }^{3}$ Perceraian merupakan jalan terakhir karena dampak buruknya tidak sedikit dan sangat serius, sehingga dalam sebuah hadist yang diriwayatkan oleh Ibn Umar, Nabi SAW menyatakan :4

$$
\text { أبغض الحلا ل الى الله تعالى الطلاق. (رواه ابو داود و الحاكم) }
$$

"Dari Ibn Umar bahwasanya nabi Muhammad SAW bersabda sesuatu yang halal yang paling dibenci oleh Allah adalah perceraian. (HR. abu Dawud)"5

Setelah perceraian, tidak hanya kata-kata cerai dan kemudian pasangan tersebut bisa berpisah begitu saja. Akan ada lagi masalah-maslah yang akan mereka selesaikan selanjutnya, seperti permasalahan hak asuh anak, dan harta bersama. Secara bahasa, harta bersama adalah dua kata terdiri dari kata harta dan bersama. Menurut Kamus Besar Bahasa Indonesia "harta dapat berarti barangbarang (uang dan sebagainya) yang menjadi kekayaan, baik kekayaan yang berwujud maupun yang tidak berwujud dan tentunya bernilai. Harta bersama berarti yang digunakan atau dimanfaatkan secara bersama-sama. ${ }^{6}$

Sebagaimana yang diatur di dalam Undang-Undang perkawinan No 1 tahun 1974 pasal 35 dan 36 disana telah dijelaskan tentang perbedaan harta dalam perkawinan. Harta tersebut adalah harta pribadi(bawaan) dan harta bersama. Harta pribadi berupa harta yang telah dimiliki suami istri sebelum perkawinan berlangsung dan tetap seutuhnya menjadi milik pribadu.Tidak ikut bercampur ke dalam harta bersama.

Pasal 35 ayat 1: "Harta benda yang diperoleh selama perkawinan menjadi harta bersama," ayat 2: "Harta bawaan dari masing-masing suami dan istri dan harta benda yang diperoleh masing-masing sebagai hadiah atau warisan, adalah dibawah penguasaan masing-masing sepanjang para pihak tidak menentukan lain."7 Adapun menurut KHI pasal 97: "Janda atau duda cerai masing-masing berhak seperdua dari harta bersama sepanjang tidak ditentukan lain dalam perjanjian perkawinan".8

Sebagaimana di dalam surat gugatan Pengadilan Agama Tembilahan No:0233/Pdt.G/2018/PA.Tbh bahwa penggugat dalam surat gugatannya tanggal 14 maret 2018 telah mengajukan gugatan Harta Bersama, yang telah terdaftar dikepaniteraan Pengadilan Agama Tembilahan dengan Nomor 0233/Pdt.G/2018/PA.Tbh dengan dalil dalil pokoknya sebagai berikut:

1. Pada awalnya Penggugat dengan tergugat adalah suami isteri yang menikah pada hari senin tanggal 17 maret 2008 sebagaimana Kutipan Akta Nikah Nomor:096/05/IV/2008 kemudian bercerai pada tanggal 20 Desember 2017 dengan putusan Pengadilan Agama tembilahan Nomor: 0794/Pdt.G/2017/PA.Tbh.

\footnotetext{
${ }^{3}$ Ahmad Rofiq, Hukum Islam di Indonesia (Jakarta: Raja Grafindo Persada,2000).240

${ }^{4}$ Slamet Aminuddin, Fikih Munakahat (Bandung: Cv Pustaka Setia,1999).15

${ }^{5}$ Abu Daud, Sunan Abu Daud, (Beirut: Dar Risalah Al-Alamiah, 2009).505

6 Pusat Pembinaan Dan Pengembangan Bahasa Departemen Pendidikan Dan Kebudayaan, Kamus Besar Bahas Indonesia, Edisi Kedua Cet-4 (Jakarta: Balai Pustaka, 1995).342

7 Pustaka Yustisia, Hukum Keluarga (Jakarta: 2010).291

8 Direktorat Pembinaan Peradilan Agama Islam, Kompilasi Hukum Islam, BAB XIII Pasal 97.
} 
2. Selama perkawinan, dalam membina rumah tangga selama kurang lebih 9 tahun, penggugat dan tergugat telah memiliki harta bersama berupa antara lain yaitu sebidang tanah Sertifikat Hak Milik Nomor 1086 atas nama saudara Tergugat seluas $244 \mathrm{M}^{2}$, diatasnya berdiri sebuah bangunan rumah tembok permanen seluas kurang lebih 151,62 $\mathrm{M}^{2}$ yang ditaksir harganya kurang lebih Rp. 800.000.000.9

Sesuai dengan KHI Pasal 97: "Janda atau duda cerai masing-masing berhak seperdua dari harta bersama sepanjang tidak ditentukan lain dalam perjanjian perkawinan." Namun pada realitanya pada Putusan Nomor: 0233/Pdt.G/2018/PA.Tbh bahwa Hakim Pengadilan Agama Tembilahan memutuskan Penggugat (suami) mendapatkan $1 / 4$ sedangkan Tergugat (isteri) mendapatkan $3 / 4$ dari Harta Bersama. ${ }^{10}$

Adapun hasil yang hendak dicapai dari penelitian ini adalah Untuk mengetahui Pertimbangan Hakim dalam menetapkan Harta Bersama dalam putusan No.0233/Pdt.G/2018/PA.Tbh di Pengadilan Agama Tembilahan Kelas II dan Untuk mengetahui pandangan Hukum Islam terhadap penetapan putusan No.0233/Pdt.G/2018/PA.Tbh di Pengadilan Agama Tembilahan Kelas II.

\section{Harta Bersama}

Harta bersama merupakan harta kekayaan yang diperoleh selama perkawinan di luar warisan atau hadiah, maksudnya adalah harta yang diperoleh atas usaha mereka atau sendiri-sendiri selama masa ikatan perkawinan. ${ }^{11}$ Secara bahasa, harta bersama adalah dua kata terdiri dari kata harta dan bersama. Menurut Kamus Besar Bahasa Indonesia, Harta dapat berarti barang-barang(uang dan sebagainya) yang menjadi kekayaan yang berwujud maupun yang tidak berwujud dan tentunya yang bernilai. Harta bersama berarti harta yang dipergunakan (dimanfaatkan) bersama-sama. ${ }^{12}$

Harta bersama merupakan salah satu macam dari sekian banyak harta yang dimiliki seseorang. Dalam kehidupan sehari-hari harta mempunyai arti penting bagi seseorang karena dengan memiliki harta dapat memenuhi kebutuhan hidup secara wajar dan memperoleh status sosial yang baik dalam masyarakat. Namun harta bersama tersebut akan menjadi harta yang tidak lagi dapat disebut sebagai harta bersama ketika telah terjadi cerai mati atau perceraian. ${ }^{13}$ Dalam kehidupan sehari-hari, harta mempunyai arti penting bagi seseorang karena dengan memiliki harta, dia dapat memenuhi kebutuhan hidup secara wajar dan memperoleh status social yang baik dalam masyarakat. Arti penting tersebut tidak hanya dari segi kegunaannya (aspek ekonomi) melainkan juga dari segi keteraturannya (aspek hukum).

\footnotetext{
${ }^{9}$ Salinan Putusan Nomor. 0233/Pdt.G/2018/PA.Tbh.2

10 Salinan Putusan Nomor. 0233/Pdt.G/2018/PA.Tbh.37

${ }^{11}$ Ahmad Rafiq, Hukum Islam di Indonesia (Cet. 4; Jakarta: Raja Grafindo Persada, 2000).200

12 Wasman dan Wardah Nuroniyah, Hukum Perkawinan Islam di Indonesia (Yogyakarta: CV.Mitra Utama, 2011).217

${ }^{13}$ H.M.A Tihami dan Sohari Sahrani, Fikih Munakahat Kajian Fikih Nikah Lengkap (Jakarta: Rajawali Pers, 2010).179
} 
Harta kekayaan dalam perkawinan atau syirkah adalah harta yang diperoleh baik sendiri-sendiri atau bersama suami istri selama dalam ikatan perkawinan berlangsung dan selanjutnya disebut harta bersama. Dalam kitabkitab fiqih tidak dikenal adanya pembauran harta suami istri setelah berlangsungnya perkawinan. Suami memiliki hartanya sendiri dan istri memiliki hartanya sendiri. Sebagai kewajibannya, suami memberikan sebagian hartanya itu kepada istrinya atas nama nafaqah, yang untuk selanjutnya digunakan istri bagi keperluan rumah tangganya. Tidak ada penggabungan harta, kecuali dalam bentuk syirkah. Tanpa akad tersebut harta tetap terpisah. ${ }^{14}$

Hukum Islam Hanya mengenal syirkah. Harta bersama dalam perkawinan termasuk syirkah abdan mufawwadah, dikatakan syirkah afdan karena suami istri secara bersama-sama bekerja membanting tulang dalam mencari nafkah seharihari. Dikatakan syirkah mufawwadah karena perkongsian antara suami istri itu tidak terbatas. ${ }^{15}$ Berdasarkan pengertian mengenai harta bersama sebagaimana diatas, jelaslah bahwa harta bersama adalah harta kekayaan yang diperoleh selama perkawinan diluar warisan atau hadiah, maksudnya adalah harta yang diperoleh atas usaha mereka atau sendiri-sendiri selama masa ikatan setelah terjadinya suatu perkawinan yang akan membawa konsekuensi kedudukan harta benda, baik harta tetap maupun harta bergerak yang diperoleh sepanjang perkawinan adalah menjadi hak bersama antara suami isteri tanpa membedakan ataupun mempersoalkan siapa yang bekerja, siapa yang memperoleh uang yang digunakan untuk membeli harta benda tersebut dan juga tanpa mempersoalkan harta benda tersebut diatasnamakan suami ataupun isteri. 16

Mengenai pengertian harta bersama diatas terdapat dalam Kompilasi Hukum Islam, juga terdapat dalam pasal 35 Undang-undang No.1 tahun 1974 tentang Perkawinan, ayat (1) menyatakan: "Harta benda yang diperoleh selama perkawinan menjadi harta bersama." Sedang ayat (2) menyatakan:

"Harta bawaan dari masing-masing suami dan isteri dan harta benda yang diperoleh masing-masing sebagai hadiah atau warisan adalah dibawah penguasaan masing-masing sepanjang para pihak tidak menentukan lain."17

\section{Desar dan Ruang Lingkup Hukum Harta Bersama}

Pada dasarnya, harta suami istri terpisah. Jadi masing-masing mempunyai hak milik untuk menggunakan atau membelanjakan hartanya dengan sepenuhnya, tanpa diganggu oleh pihak lain. Dalam hukum Islam tidak mengatur adanya harta gono gini dalam perkawinan, yang ada adalah menerangkan tentang adanya hak milik pria atau wanita, sebagaimana dalam firman Allah, yaitu:

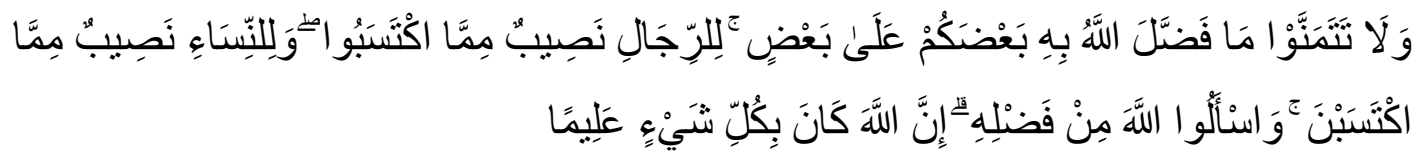

\footnotetext{
14 Mardani, Hukum Keluarga Islam di Indonesia (Cet. 1; Jakarta: Kencana, 2016).98

15 Zainuddin Ali, Hukum Perdata Islam di Indonesia (Cet. 1; Jakarta: Sinar Grafika, 2006).154

${ }^{16}$ Ahmad Rafiq, Hukum Islam di Indonesia.200

17 Undang-undang No.1 tahun 1974, Direktorat Pembinaan Badan Peradilan Agama Islam, Direktorat Jendral Pembinaan Kelembagaan Agama Islam DEPAG RI tahun 2001.
} 
"Dan janganlah kamu iri hati terhadap apa yang dikaruniakan Allah kepada sebahagian kamu lebih banyak dari sebahagian yang lain. (karena) bagi orang laki-laki ada bahagian dari pada apa yang mereka usahakan, dan bagi para wanita (pun) ada bahagian dari apa yang mereka usahakan, dan mohonlah kepada Allah sebagian dari karunia-Nya. Sesungguhnya Allah Maha mengetahui segala sesuatu." 18

Pada penjelasan tafsir Al-Maraghi dijelaskan Allah telah membebani kaum laki-laki dan wanita dengan berbagai pekerjaan. Kaum laki-laki mengerjakan perkara-perkara yang khusus untuk mereka, dan mereka memperoleh bagian khusus pula dari pekerjaan itu tanpa disertai kaum wanita. Kaum wanita mengerjakan berbagai pekerjaan yang diperuntukkan bagi mereka, dan mereka memperoleh bagian khusus dari pekerjaan itu tanpa disertai oleh kaum pria. Masing-masing merekka tidak boleh iri terhadap apa yang telah dikhususkan bagi yang lainnya. ${ }^{19}$

Ayat tersebut bersifat umum tidak ditujukan terhadap suami ataupun istri melainkan semua pria dan wanita. Jika mereka berusaha dalam kehidupannya sehari-hari, maka usaha mereka itu merupakan harta pribadi yang dimiliki dan dikuasai oleh pribadi masing-masing. Dalam konteks konvensional, suami adalah yang berkewajiban menanggung beban ekonomi, sedangkan istri adalah berperan sebagai ibu rumah tangga yang bertindak sebagai manajer yang mengatur manajemen ekonomi rumah tangga dalam pengertian yang lebih luas. Sejalan dengan tuntutan perkembangan zaman, istri juga dapat melakukan pekerjaan yang mendatangkan kekayaan. Jika yang pertama digolongkan ke dalam syirkah alabdan, yaitu modal dari suami sedangkan istri andil jasa dan tenaganya. Adapun yang kedua, adalah dimana masing-masing mendatangkan modal, suami bekerja dan istri juga bekerja lalu dikelolah bersama, hal ini disebut syirkah al-inan. ${ }^{20}$

\section{Ruang Lingkup Harta Bersama}

Menurut Sayuti Thalib, terjadinya percampuran harta dapat dilaksanakan dengan mengadakan perjanjian secara nyata-nyata tertulis atau diucapkan sebelum atau sesudah berlangsungnya akad nikah dalam suatu perkawinan, baik untuk harta bawaan masing-masing atau harta yang diperoleh selama dalam perkawinan tetapi bukan atas usaha mereka sendiri ataupun harta pencaharian. Dapat pula ditetapkan dengan undang-undang atau peraturan perundangan, bahwa harta yang diperoleh atas usaha salah seorang suami atau istri atau keduaduanya dalam masa adanya hubungan perkawinan yaitu harta pencaharian adalah harta bersama suami istri tersebut. ${ }^{21}$

Kemudian untuk memperjelas status kepemilikan harta dalam perkawinan, termasuk dalam harta bersama atau harta pribadi. Yahya harahap telah

\footnotetext{
18 Kementrian Agama RI. 84

${ }^{19}$ Ahmad Mustafa Al-Maragi, Terjemahan Tafsir Al-Maraghi 5, (Semarang: Toha Putra 1993).35

20 Ahmad Rofiq.201

21 Sayuti Thalib, Hukum Kekeluargaan (Jakarta: PT Raja Grafindo, 1998),84
} 
mengemukakan tentang ruang lingkup harta bersama yang diperoleh selama perkawinan, yaitu: ${ }^{22}$

a. Harta yang dibeli selama perkawinan

b. Harta yang dibeli dan dibangun sesudah perceraian yang dibiayai dari harta bersama

c. Harta yang dapat dibuktikan dan diperoleh selama perkawinan

d. Penghasilan harta bersama dan harta bawan

e. Segala penghasilan pribadi suami istri

Jika melihat asal-usul harta yang didapat dari suami-isteri, maka dapat disimpulkan bahwa harta tersebut dapat dibedakan dalam empat sumber yaitu:23

a. Harta hibah dan harta warisan yang diperoleh dari salah seorang suami atau isteri.

b. Harta hasil usaha sendiri sebelum mereka menikah.

c. Harta yang diperoleh pada saat perkawinan atau karena perkawinan.

d. Harta yang diperoleh selama perkawinan selain dari hibah, khusus untuk salah seorang dari suami-isteri dan selain dari harta warisan.

\section{Pertimbangan Hakim dalam Memutuskan Perkara}

Pertimbangan hakim merupakan salah satu aspek terpenting dalam menentukan terwujudnya nilai dari suatu putusan hakim yang mengandung keadilan (ex aequo et bono) dan mengandung kepastian hukum, di samping itu juga mengandung manfaat bagi para pihak yang bersangkutan sehingga pertimbangan hakim ini harus disikapi dengan teliti, baik, dan cermat.

Pada pemeriksaan suatu perkara juga memerlukan adanya pembuktian, dimana hasil dari pembuktian itu akan digunakan sebagai bahan pertimbangan dalam memutus perkara. Pembuktian merupakan tahap yang paling penting dalam pemeriksaan di persidangan. Pembuktian bertujuan untuk memperoleh kepastian bahwa suatu peristiwa/fakta yang diajukan itu benar-benar terjadi, guna mendapatkan putusan hakim yang benar dan adil. Hakim tidak dapat menjatuhkan suatu putusan sebelum nyata baginya bahwa peristiwa / fakta tersebut benarbenar terjadi, yakni dibuktikan kebenaranya, sehingga nampak adanya hubungan hukum antara para pihak.

Selain itu, pada hakikatnya pertimbangan hakim hendaknya juga memuat tentang hal-hal sebagai berikut:

a. Pokok persoalan dan hal-hal yang diakui atau dalil-dalil yang tidak disangkal.

b. Adanya analisis secara yuridis terhadap putusan segala aspek menyangkut semua fakta/hal-hal yang terbukti dalam persidangan.

c. Adanya semua bagian dari petitum Penggugat harus dipertimbangkan/diadili secara satu demi satu sehingga hakim dapat

22 Yahya Harahap, Kedudukan Kewenangan dan Acara Peradilan Agama (Jakarta: Sinar Grafika, 2003).275-278

${ }^{23}$ Wasman dan Wardah Nuroniyah.219 
menarik kesimpulan tentang terbukti/tidaknya dan dapat dikabulkan/tidaknya tuntutan tersebut dalam amar putusan.

Dasar hakim dalam menjatuhkan putusan pengadilan perlu didasarkan kepada teori dan hasil penelitian yang saling berkaitan sehingga didapatkan hasil penelitian yang maksimal dan seimbang dalam tataran teori dan praktek. Salah satu usaha untuk mencapai kepastian hukum kehakiman, di mana hakim merupakan aparat penegak hukum melalui putusannya dapat menjadi tolak ukur tercapainya suatu kepastian hukum.

Pokok kekuasaan kehakiman diatur dalam Undang-undang Dasar 1945 Bab IX Pasal 24 dan Pasal 25 serta di dalam Undang-undang Nomor 48 tahun 2009. Undang-undang Dasar 1945 menjamin adanya sesuatu kekuasaan kehakiman yang bebas. Hal ini tegas dicantumkan dalam Pasal 24 terutama dalam penjelasan Pasal 24 ayat 1 dan penjelasan Pasal 1 ayat (1) UU No. 48 Tahun 2009, yaitu kekuasaan kehakiman adalah kekuasaan negara yang merdeka untuk menyelenggarakan peradilan guna menegakkan hukum dan keadilan berdasarkan pancasila dan Undang-undang Negara Republik Indonesia tahun 1945 demi terselenggaranya Negara Hukum Republik Indonesia. ${ }^{24}$

Kebebasan hakim perlu pula dipaparkan posisi hakim yang tidak memihak (impartial jugde) Pasal 5 ayat (1) UU No. 48 Tahun 2009.Istilah tidak memihak di sini haruslah tidak harfiah, karena dalam menjatuhkan putusannya hakim harus memihak yang benar. Dalam hal ini tidak diartikan tidak berat sebelah dalam pertimbangan dan penilaiannya. Lebih tapatnya perumusan UU No. 48 Tahun 2009 Pasal 5 ayat (1): "Pengadilan mengadili menurut hukum dengan tidak membedabedakan orang." 25

Kewenangan yang diberikan kepada Hakim untuk mengambil suatu kebijaksanaan dalam memutus perkara, diatur dalam Pasal 5 Ayat (1) UndangUndang Nomor 48 Tahun 2009 tentang Kekuasaan Kehakiman, yang menentukan : "Hakim dan Hakim konstitusi wajib menggali, mengikuti dan memahami nilai-nilai hukum dan rasa keadilan yang hidup dalam masyarakat."

Berdasarkan aturan hukum tersebut, terdapat norma hukum "mewajibkan Hakim untuk menggali, mengikuti dan memahami nilai-nilai hukum dan rasa keadilan yang hidup dalam masyarakat. Untuk memenuhi norma tersebut, maka Hakim harus mengambil kebijaksanaan hukum." Penentuan atas tuntutan rasa keadilan yang harus diterapkan oleh Hakim dalam memutus suatu perkara, secara teori para Hakim akan melihat "Konsep-konsep keadilan yang telah baku" Dalam konsep ini keadilan merupakan kewajiban moral yang mengikat para anggota masyarakat dalam hubungannya yang satu terhadap yang lainnya.

Ciri atau sifat konsep keadilan dapat diikhtisarkan maknanya sebagai berikut: adil (just), bersifat hukum (legal), sah menurut hukum (lawful), tak memihak (impartial), sama hak (equal), layak (fair), wajar secara moral (equitable), benar secara moral (righteous). Dari perincian tersebut ternyata bahwa pengertian konsep keadilan mempunyai makna ganda yang perbedaannya satu dengan yang lain samar-samar atau kecil sekali. Dalam setiap pengambilan

\footnotetext{
${ }^{24}$ Mukti Arto, Praktek Perkara Perdata pada Pengadilan Agama (Yogyakarta, Pustaka Pelajar, 2004).142

${ }^{25}$ Andi Hamzah, KUHP dan KUHAP (Jakarta, Rineka Cipta, 1996).95
} 
kebijaksanaan oleh Hakim, maka Hakim selalu berlindung kepada Upaya Hukum yaitu Banding, Kasasi dan Peninjauan Kembali, artinya apabila Hakim Tingkat Pertama mengambil kebijaksanaan dalam memutus perkara tidak sesuai dengan norma-norma hukum yang harus dipatuhi, maka solusinya dipersilahkan naik banding untuk diuji kebijaksanaan tersebut, demikian pula kebijaksanaan hukum yang diambil oleh Hakim Tingkat banding apabila melanggar standard suatu norma hukum, pengujiannya melalui Kasasi Mahkamah Agung RI dan seterusnya sampai pengujian di Peninjauan Kembali, oleh karena itu diperlukan norma hukum sebagai standard bagi para Hakim dalam hal pengambilan suatu kebijaksanaan hukum untuk memutus perkara. ${ }^{26}$

Terdapat 6 (enam) prinsip penting yang harus dijadikan pegangan bagi para hakim di dunia sebagaimana tercantum dalam The Bangalore Principle, yakni:
a. Independensi
b. Ketidakberpihakan
c. Integritas
d. Kepantasan dan Kesopanan
e. Kesetaraan
f. Kecakapan dan Keseksamaan

\section{Putusan Hakim dalam Penyelesaian Perkara Harta Bersama}

Menimbang, bahwa menurut Undang-Undang Nomor 1 tahun 1974 tentang Perkawinan pada pasal 35 ayat 1 yang menyatakan bahwa "Harta yang diperoleh selama perkawinan menjadi harta benda bersama." Menimbang, bahwa dalam fakta persidangan terbukti bahwa penggugat dan Tergugat pernah terikat dalam perkawinan yang sah dimulai sejak tanggal 17 Maret 2008 sampai dengan 20 Desember 2017 berdasarkan Putusan Pengadilan Agama Tembiahan Nomor 0794/Pdt.G/2017/PA.Tbh.

Menimbang, bahwa dalam fakta persidangan terbukti bahwa selama menjalani perkawinan yang sah, Penggugat dan Tergugat telah memiliki sebidang tanah Sertifikat Hak Milik Nomor 1086 atas nama Tergugat seluas $244 \mathrm{M}^{2}$, diatasnya berdiri sebuah bangunan rumah tembok permanen seluas $\pm 151,62 \mathrm{M}^{2}$ yang terletak di Jalan Pelita Jaya RT.001 RW. 014 Kelurahan Tembilahan Hulu Kecamatan Tembilahan Hulu Kabupaten Indragiri Hilir Provinsi Riau, yang ditaksir harganya \pm Rp. 800.000.000,- (Delapan Ratus Juta Rupiah), dengan luas tanah 244 $\mathrm{M}^{2}$, dengan batas-batas sekarang sebagai berikut:

a. Sebelah Utara berbatas dengan tanah As'ad yaitu \pm 35 Meter

b. Sebelah Selatan berbatasan dengan tanah Syofran yaitu \pm 35 Meter

c. Sebelah Barat berbatasan dengan tanah Hj.Ukis yaitu $\pm 6,97$ Meter

d. Sebelah Timur berbatasan dengan Jalan Pelita Jaya yaitu $\pm 6,97$ Meter.

Menimbang, bahwa berdasarkan pertimbangan tersebut diatas terbukti bahwa objek sengketa merupakan bagian dari harta benda yang diperoleh selama perkawinan antar penggugat dan tergugat, dengan demikian gugatan Penggugat a quo sudah sepatutnya untuk dikabulkan dengan mengabulkan petitum angka 2 dari gugatan Penggugat sebagaimana akan dicantumkan dalam dictum putusan ini.

\footnotetext{
${ }^{26}$ Satjipto, Hukum dan Masyarakat (Bandung:Angkasa,1980).12
} 


\section{Tentang Bagian Masing-Masing Penggugat dan Tergugat}

Adapun menurut hakim Pengadilan Agama Tembilahan dalam putusan nya tentang bagian masing-masing Penggugat dan Tergugat adalah sebagai berikut:

1. Hakim dalam menjalankan jabatannya harus memastikan terciptanya kepastian hukum dan keadilan hukum bagi setiap pencari keadilan.

2. Pasal 97 Kompilasi Hukum Islam menyatakan bahwa; "Janda atau duda cerai hidup maasing-masing berhak seperdua dari harta bersama sepanjang tidak ditentukan lain dalam perjanjian perkawinan"

3. Akan tetapi jika peraturan ini diberlakukan secara kaku dalam perkara $a$ quo justru akan mereduksi nilai-nilai keadilan itu sendiri, dengan demikian Majelis Hakim akan memberi pandangan tersendiri terhadap bagian masing-masing pihak baik Penggugat maupun Tergugat.

4. Secara garis besar Undang-undang Nomor 1 tahun 1974 tentang perkawinan dan Kompilasi Hukum Islam mengatur tentang Hak dan Kewajiban masing-masing suami-isteri dalam menjalankan perannya sebagai suami dan/ isteri.

5. Ketentuan Pasal 97 Kompilasi Hukum Islam dapat diterapkan jika selama dalam menjalani perkawinan Penggugat dan Tergugat menjalankan tugas dan fungsinya sebagaimana kehendak Undang-undang Nomor 1 tahun 1974 tentang Perkawinan dan Kompilasi Hukum Islam, dimana keduanya mengatur tentang peran Suami dan Isteri dalam berumah tangga. Bahwa suami bertugas mencari nafkah, menyediakan tempat tinggal dan memastikan terpenuhinya hak-hak isteri, sedangkan isteri bertugas mengurus rumah tangga dan menjaga kehormatan dirinya dan suaminya.

6. Jika kondisi diatas terpenuhi, maka barulah pembagian harta Bersama dalam perkawinan dapat dilakukan berdasarkan ketentuan Pasal 97 Kompilasi Hukum Islam, namun jika kondisi tersebut tidak terpenuhi, maka pembagian Harta Bersama harus ditinjau ulang dengan mengedepankan nilai-nilai keadilan.

7. Dalam fakta persidangan terbukti secara sah dan meyakinkan bahwa selama menjalani perkawinan sejak tahun 2008 sampai dengan tahun 2017, Tergugat berperan lebih dominan dalam mencari nafkah dan menghasilkan harta, yang kemudian harta tersebut menjadi objek sengketa Harta Bersama dalam perkara a quo.

8. Berdasarkan Pertimbangan-pertimbangan di atas, ditambah dengan persangkaan menurut Hakim, maka untuk menjaga agar nilai-nilai keadilan tetap tercermin dalam putusan ini, terutama menyangkut amanat Undangundang untuk memberikan jaminan keadilan bagi kaum yang lemah (feminine justice) maka Hakim berpendapat menetapkan bagian masingmasing pihak terhadap Harta Benda objek sengketa yang menjadi Harta Bersama selama perkawinan Penggugat dan Tergugat adalah $1 / 4$ (seperempat) bagian untuk Penggugat dan $3 / 4$ (tiga perempat) bagian untuk tergugat. ${ }^{27}$

\footnotetext{
${ }^{27}$ Salinan Putusan Pengadilan Agama Tembilahan
} 
Bahwasanya hakim memutuskan perkara itu berdasarkan Legal Certainty (kepastian hukum) dan Legal Justice (keadilan hukum), kepastian hukum adalah apa yang sudah digariskan oleh peraturan perundang-undangan, Kompilasi Hukum islam, seperti perkara ini menurut legal certainty maka pembagian nya adalah isteri mendapat $1 / 2$ dan suami pun mendapat $1 / 2$ maka jika hanya ini yang diberlakukan secara kaku dalam perkara tersebut akan mereduksi nilai-nilai keadilan itu sendiri, dengan demikian hakim dalam menetapkan perkara harta bersama ini menggunakan Legal Justice (Keadilan Hukum), adapun keadilan hukum ini di dapat dari fakta persidangan yang didapat dari kedua belah pihak yang berperkara mulai dari gugatan, jawaban, replik, duplik, surat, keterangan saksi yang mana semuanya itu harus diuji di sidang pembuktian dan disidang pembuktianlah hakim mendapatkan konklusi (pendapat, simpulan) yang mana menetapkan $1 / 4$ (seperempat) bagian untuk suami dan $3 / 4$ (tiga perempat) bagian untuk isteri sebagaimana dicantumkan dalam diktum putusan. ${ }^{28}$

Setelah penulis melakukan pengamatan dan wawancara, penulis menemukan fakta yang ada didalam persidangan adapun fakta-fakta tersebut sebagai berikut:

a. Pada 05 November 2008 Tergugat (Isteri) membeli tanah beserta rumah satu lantai semi permanen di atasnya dari Agusman setelah 3 bulan pernikahan dengan harga Rp. 145.000.000,00 (seratus empat puluh lima juta rupiah)

b. Kurang lebih 9 tahun pernikahan penggugat (suami) hanya 3 tahun bekerja.

c. Pada tahun 2011-2015 penggungat (suami) memproduksi bakso dan memasarkannya sendiri (home industry) sedangkan tergugat (isteri) sebagai PNS.

d. Rumah telah di renovasi dua kali pada tahun 2012 dan 2017 tergugat dengan uang hasil peminjaman uang adik tergugat (isteri) dan uang hasil peminjaman bank sehingga berbentuk rumah permanen 2 lantai.

e. Saat renovasi rumah yang kedua pada tahun 2017 Penggugat (suami) sudah tidak bekerja lagi.

f. Saat renovasi rumah yang pertama Penggugat (suami) memberikan sejumlah uang sebesar Rp. 15.000.000,00 (lima belas juta rupiah).

\section{Pandangan Hukum Islam Terhadap Putusan No: 0233/Pdt.G/2018/PA.Tbh.}

Bahwasanya dalam berumah tangga suami bertugas mencari nafkah, menyediakan tempat tinggal dan memastikan terpenuhinya hak-hak istri, Kita telah mengetahui bahwa perkawinan sebagaimana halnya akad yang lain menimbulkan berbagai hak dan kewajiban antara suami dan isteri, sebagai pelaksanaan prinsip keseimbangan, kesetaraan, dan persamaan berbagai pihak yang melaksanakan akad.

Al-Qur'an telah mengisyaratkan prinsip ini tetapnya hak-hak dan kewajibannya. Allah SWT berfirman;

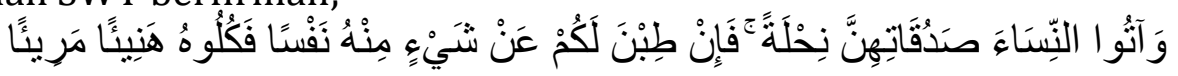

\footnotetext{
${ }^{28}$ Wawancara hakim Pengadilan Agama Tembilahan 02 April 2019
} 
"Berikanlah maskawin (mahar) kepada wanita (yang kamu nikahi) sebagai pemberian dengan penuh kerelaan"(QS An-Nisa:4) 29

Maksudnya, isteri memiliki berbagai hak yang harus dipenuhi oleh laki-laki, sebagaimana halnya isteri juga memiliki berbagai kewajiban yang harus dia penuhi untuk si suami. ${ }^{30}$ Kewajiban suami yang kedua setelah memberi mahar kepada istrinya awal pernikahan, adalah memberi nafkah secara rutin. Nafkah adalah harta pemberian suami kepada istri, yang sesuai diberikan, maka harta itu berubah status kepemilikannya, menjadi milik istri. ${ }^{31}$

Namun pada faktanya dalam pernikahan ini kondisi tersebut tidak terpenuhi dan adanya perubahan kondisi dari yang sebenarnya, yang mana seharusnya hakim menggunakan pasal 97 Kompilasi Hukum islam dalam pembagian harta bersama ini, maka hakim memutuskan pembagian harta bersama tidak menggunakan pasal 97 Kompilasi Hukum Islam dikarenakan Penggugat dan Tergugat tidak menjalankan tugas dan fungsinya sebagaimana kehendak Undangundang Nomor 1 tahun 1974 tentang Perkawinan dan Kompilasi Hukum Islam dimana keduanya mengatur peran suami dan istri dalam berumah tangga, jika kondisi sebagaimana dimaksud terpenuhi maka barulah pembagian harta bersama dalam perkawinan dapat dilakukan berdasarkan pasal 97 Kompilasi Hukum Islam, namun jika kondisi tersebut tidak terpenuhi maka pembagian harta harus ditinjau ulang dengan mengedepankan nilai-nilai keadilan. Maka dari itu penjelasan diatas adanya perubahan kondisi dari yang sebenarnya hal ini juga sesuai dengan kaidah ushul fiqh yaitu:

$$
\text { تغير الاحكام بتغير الزمان و المكان و الاحو ال }
$$

"Perubahan hukum terjadi dengan berubahnya zaman, tempat, keadaan."32

Menurut hemat penulis putusan hakim dengan mengedepankan nilai-nilai keadilan sudah tepat, yang mana merujuk dari fakta persidangan dan putusan bahwasanya istri lebih dominan dalam menghasilakan harta dibandingkan suami selama kurang lebih 9 tahun perkawinan dan istri juga yang membeli tanah beserta rumah tersebut yang menjadi objek sengketa pada perkara ini. Adapun konsep keadilan dalam islam adalah menempatkan sesuatu pada tempatnya, membebankan sesuatu sesuai daya pikul seseorang, memberikan sesuatu yang memang menjadi haknya dengan kadar yang seimbang. Konsep keadilan yang merupakan prinsip kedua setelah tauhid meliputi keadilan dalam berbagai hubungan: hubungan antara individu dengan dirinya sendiri, hubungan antara individu dengan manusia dan masyarkatnya, hubungan antara individu dengan hakim dan yang berperkara serta hubungan-hubungan dengan berbagai pihak yang terkait. Al-Qur'an memperingatkan dalam berbagai ayat bahwa jiwa manusia

\footnotetext{
${ }^{29}$ Kementerian Agama RI. 77

30Wahbah Az-Zuhaili, Fiqih Islam Wa Adillatuhu (Jakarta: Gema Insani, 2011).294

${ }^{31}$ Ahmad Sarwat, Ensiklopedia Fikih Indonesia 8: Pernikahan (Jakarta: Gramedia Pustaka Utama, 2019).159

32Muchlis Usman, Kaidah-kaidah Ushuliyyah dan Fiqhiyyah (Jakarta: Raja Grafindo Persada, 1999).145
} 
cenderung mengikuti hawa nafsu. Kecintaan dan kebencian merupakan faktor yang memungkinkan manusia mendahulukan kebatilan daripada kebenaran, mendahulukan kealiman daripada keadilan.

Allah memerintahkan manusia untuk berlaku adil dalam segala hal. keharusan berlaku adil itu terutama ditujukan kepada mereka yang mempunyai kekuasaan, atau yang mempunyai hubungan dengan kekuasaan. Mereka adalah para pemimpin yang berpengaruh terhadap masyarakat. Karena prinsip keadilan ini pulalah kiranya lahir kaidah yang menyatakan bahwa hukum islam dalam praktiknya dapat berubah sesuai dengan ruang dan waktu, seperti yang sudah dijelaskan pada kaidah diatas. ${ }^{33}$ Selanjutnya hakim mengedepankan nilai-nilai keadilan dalam putusan harta bersama ini dan memutuskan tergugat (istri) mendapat lebih besar yaitu $3 / 4$ dan penggugat (suami) mendapat $1 / 4$. Bahwasanya landasan hakim menurut fakta persidangan selama kurang lebih 9 tahun pernikahan suami hanya 3 tahun bekerja, sehingga istri yang lebih dominan menghasilkan harta, yang kemudian harta tersebut menjadi sumber membeli dan merenovasi rumah yang menjadi objek sengketa harta bersama. untuk keperluan sehari-hari maupun keperluan lainnya.

Sebagaimana yang dimaksud dari penjelasan diatas, adapun isi dari putusan hakim pada perkara harta bersama antara Penggugat (suami) dan Tergugat (istri) adalah sebagai berikut: ${ }^{34}$

1. Mengabulkan Gugatan Penggugat

2. Menetapkan sebidang tanah sertifikat Hak Milik Nomor 1086 seluas $244 \mathrm{M}^{2}$ atas nama Tergugat (istri), dengan sebuah rumah tembok permanen 2 (dua) lantai di atasnya dengan luas bangunan 151,62 $\mathrm{M}^{2}$ yang terletak di jalan Pelita Jaya RT 001 RW 014 Kelurahan Tembilahan Hulu Kecamatan Tembilahan Hulu Kabupaten Indragiri Hilir Provinsi Riau, dengan batasbatas sebagai berikut: Pertama, Sebelah Utara berbatas dengan tanah As'ad sepanjang \pm 35 Meter. Kedua, sebelah Selatan berbatasan dengan tanah Syofran sepanjang \pm 35 Meter. Ketiga, sebelah Barat berbatasan dengan tanah Hj.Ukis alias Hj. Bulkis sepanjang \pm 6,97 Meter. Keempat, sebelah Timur berbatasan dengan Jalan Pelita Jaya sepanjang $\pm 6,97$ Meter adalah harta bersama milik Penggugat dan Tergugat.

3. Menetapkan penggugat berhak memiliki $1 / 4$ (seperempat) bagian dari harta bersama sebagaimana tersebut pada amar di atas dan Tergugat berhak memiliki 3/4 (tiga perempat) bagian dari harta bersama sebagaimana tersebut pada amar tersebut diatas.

4. Menghukum Tergugat dan Penggugat supaya membagi harta bersama sebagaimana tersebut pada amar nomor (2) dan apabila tidak dapat dibagi secara natura supaya menjualnya secara lelang di muka umum dan menyerahkan hasilnya kepada masing-masing sebagaimana disebut pada amar nomor (3).

5. Menghukum Penggugat untuk membayar biaya perkara yang timbul sebesar Rp. 1.941.000.00,- (satu juta Sembilan ratus empat puluh satu ribu rupiah).

\footnotetext{
33Juhaya S. Praja.73

${ }^{34}$ Salinan Putusan Pengadilan Agama Tembilahan.
} 
Dengan demikian menurut penulis bahwasanya putusan hakim dalam penyelesaian perkara harta bersama No.0233/Pdt.G/2018/PA.Tbh di Pengadilan Agama Tembilahan dengan memutuskan Tergugat dalam hal ini sebagai istri mendapat $(3 / 4)$ lebih banyak dibandingkan Penggugat dalam hal ini sebagai suami yaitu $(1 / 4)$ sesuai dengan hakim dalam memutuskan perkara itu berdasarkan Legal Certainty (kepastian hukum) dan Legal Justice (keadilan hukum), kepastian hukum adalah apa yang sudah digariskan oleh peraturan perundang-undangan, Kompilasi Hukum islam, seperti perkara ini menurut legal certainty maka pembagian nya adalah isteri mendapat $1 / 2$ dan suami pun mendapat $1 / 2$ maka jika hanya ini yang diberlakukan secara kaku dalam perkara tersebut akan mereduksi nilai-nilai keadilan itu sendiri, dengan demikian hakim dalam menetapkan perkara harta bersama ini menggunakan Legal Justice (Keadilan Hukum). Dalam islam konsep keadilan adalah menempatkan sesuatu pada tempatnya, membebankan sesuatu sesuai daya pikul seseorang, memberikan sesuatu yang memang menjadi haknyadengan kadar yang seimbang.

Selama perkawinan suami istri tidak menjalankan tugas dan fungsi masingmasing sebagaimana yang tercantum didalam Undang-undang Perkawinan dan Kompilasi Hukum Islam dan Tergugat (istri) lebih dominan dalam mencari nafkah dan menghasilkan harta, yang kemudian harta tersebut menjadi sumber untuk membeli dan merenovasi rumah yang sekarang ini menjadi objek sengketa.

\section{Penutup}

Fakta persidangan terbukti secara sah dan meyakinkan bahwa selama menjalani perkawinan sejak tahun 2008 sampai dengan tahun 2017, Tergugat berperan lebih dominan dalam mencari nafkah dan menghasilkan harta, yang kemudian harta tersebut menjadi objek sengketa Harta Bersama dalam perkara $a$ quo. Maka Hakim berpendapat menetapkan bagian masing-masing pihak terhadap Harta Benda objek sengketa yang menjadi Harta Bersama selama perkawinan Penggugat dan Tergugat adalah $1 / 4$ (seperempat) bagian untuk Penggugat dan $3 / 4$ (tiga perempat) bagian untuk tergugat.

Putusan hakim dalam penyelesaian perkara harta bersama No.0233/Pdt.G/2018/PA.Tbh di Pengadilan Agama Tembilahan dengan memutuskan Tergugat dalam hal ini sebagai istri mendapat $(3 / 4)$ lebih banyak dibandingkan Penggugat dalam hal ini sebagai suami yaitu $(1 / 4)$ sesuai dengan hakim dalam memutuskan perkara itu berdasarkan Legal Certainty (kepastian hukum) dan Legal Justice (keadilan hukum), kepastian hukum adalah apa yang sudah digariskan oleh peraturan perundang-undangan, Kompilasi Hukum islam, seperti perkara ini menurut legal certainty maka pembagian nya adalah isteri mendapat $1 / 2$ dan suami pun mendapat $1 / 2$ maka jika hanya ini yang diberlakukan secara kaku dalam perkara tersebut akan mereduksi nilai-nilai keadilan itu sendiri, dengan demikian hakim dalam menetapkan perkara harta bersama ini menggunakan Legal Justice (Keadilan Hukum). Dalam Islam konsep keadilan adalah menempatkan sesuatu pada tempatnya, membebankan sesuatu sesuai daya pikul seseorang, memberikan sesuatu yang memang menjadi haknyadengan kadar yang seimbang. Selama perkawinan Tergugat (istri) lebih dominan dalam mencari nafkah dan menghasilkan harta, yang kemudian harta tersebut menjadi sumber untuk membeli dan merenovasi rumah yang sekarang ini menjadi objek sengketa. 


\section{Daftar Pustaka}

Ali, Zainuddin, 2006, Hukum Perdata Islam di Indonesia Jakarta: Sinar Grafika.

Al-Maragi, Ahmad Mustafa, 1993, Terjemahan Tafsir Al-Maraghi 5, Semarang: Toha Putra.

Aminuddin, Slamet, 1999, Fikih Munakahat, Bandung: Cv Pustaka Setia.

Arto, Mukti, 2004, Praktek Perkara Perdata pada Pengadilan Agama, Yogyakarta, Pustaka Pelajar.

Az-Zuhaili, Wahbah, 2011, Fiqih Islam Wa Adillatuhu, Jakarta: Gema Insani.

Bakry, Hasbullah, 1985, Kumpulan Lengkap Undang-undang dan Peraturan Perkawinan di Indonesia, Jakarta: Djambatan.

Daud, Abu, 2009, Sunan Abu Daud, Beirut: Dar Risalah Al-Alamiah.

Direktorat Jendral Pembinaan Kelembagaan Agama Islam DEPAG RI, 2001, Undang-undang No.1 tahun 1974, Direktorat Pembinaan Badan Peradilan Agama Islam.

Direktorat Pembinaan Peradilan Agama Islam, Kompilasi Hukum Islam, BAB XIII Pasal 97.

Hamzah, Andi, 1996, KUHP dan KUHAP, Jakarta, Rineka Cipta.

Harahap, Yahya, 2003, Kedudukan Kewenangan dan Acara Peradilan Agama, Jakarta: Sinar Grafika

Kementerian Agama RI, 2012, Al-Qur'an dan Terjemahannya, Jakarta: CV Madinatu al-'Ulum.

Mardani, 2016, Hukum Keluarga Islam di Indonesia, Jakarta: Kencana.

Pusat Pembinaan Dan Pengembangan Bahasa Departemen Pendidikan Dan Kebudayaan, 1995, Kamus Besar Bahas Indonesia, Edisi Kedua, Cet-4 Jakarta: Balai Pustaka.

Pustaka Yustisia, 2010, Hukum Keluarga, Jakarta: 2010.

Rafiq, Ahmad, 2000, Hukum Islam di Indonesia Jakarta: Raja Grafindo Persada.

Rofiq, Ahmad, 2000, Hukum Islam di Indonesia, Jakarta: Raja Grafindo Persada.

Salinan Putusan Nomor. 0233/Pdt.G/2018/PA.Tbh, Hal.2

Salinan Putusan Pengadilan Agama Tembilahan

Sarwat, Ahmad, 2019, Ensiklopedia Fikih Indonesia 8: Pernikahan, Jakarta: Gramedia Pustaka Utama.

Satjipto, 1980, Hukum dan Masyarakat, Bandung:Angkasa.

Thalib, Sayuti, 1998, Hukum Kekeluargaan, Jakarta: PT Raja Grafindo.

Tihami, M.A dan Sohari Sahrani, 2010, Fikih Munakahat Kajian Fikih Nikah Lengkap, Jakarta: Rajawali Pers.

Usman, Muchlis, 1999, Kaidah-kaidah Ushuliyyah dan Fiqhiyyah, Jakarta: Raja Grafindo Persada

Wasman dan Wardah Nuroniyah, 2011, hukum perkawinan islam di Indonesia, Yogyakarta:CV.Mitra Utama.

Wawancara hakim Pengadilan Agama Tembilahan 02 April 2019 